Click www.researchjournal.co.in/online/subdetail.html to purchase.

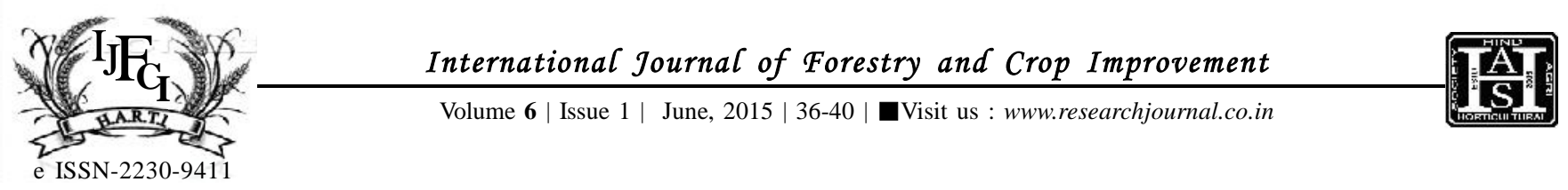

RESEARCH ARTICLE

DOI: $10.15740 / \mathrm{HAS} / \mathrm{IJFCI} / 6.1 / 36-40$

\title{
Utilization of vermiwash spray on growth and yield of radish cv. LOCAL VARIETY
}

\author{
P.B. JadhaV, A. Kireeti, D.J. Patel, S.S. Dekhane, N.B. Patil and S.J. Patil
}

\begin{abstract}
The present investigation was undertaken with the main objective of utilization of vermiwash spray on growth and yield of radish cv. LOCAL VARIETY. The experiment was laid out in Randomized Completely Block Design with five treatments and four replications. The experiment consists of five treatments involving application of water and vermiwash in the proportion of 1:1, 1:2, 1:3 and 1:4 and control were imposed and the foliar application was made by using knapsack sprayer in the evening hours twice at 15 and 30 days after sowing seeds. The data clearly revealed that the yield obtained with treatment $\mathrm{T}_{4}(100 \% \mathrm{RDF}$ as fertigation and vermiwash foliar twice times spray 1:4 at 15 and 30 days after sowing seeds) was significantly higher than all other treatments in growth and yield attributes such as root diameter $(5.53 \mathrm{~cm})$, length $(25.90 \mathrm{~cm})$, weight $(90.90 \mathrm{~g})$, yield $/ \mathrm{plot}(18.18 \mathrm{~kg})$, yield/ha (60.59 t/ha) and marketable yield ( $45.45 \mathrm{t} / \mathrm{ha})$ of radish cv. LOCAL VARIETY. Thus, it can be concluded that foliar spray of vermiwash (1:4) effective than control.
\end{abstract}

KEY WORDS : Radish, Local, Vermiwash, Water, Organic

How to CITE THIS ARTIClE : Jadhav, P.B., Kireeti, A., Patel, D.J., Dekhane, S.S., Patil, N.B. and Patil, S.J. (2015). Utilization of vermiwash spray on growth and yield of radish cv. LOCAL VARIETY. Internat. J. Forestry \& Crop Improv, 6 (1) : 36-40.

Article ChroniCAL : Received : 30.12.2014; Revised : 15.04.2015; Accepted : 18.05.2015

Email: tropicalsubtropical@gmail.com

Address of the Coopted Authors : A. KIREETI, S.S. DEKHANE AND N.B. PATIL, ASPEE, Agricultural Research and Development Foundation, MUMBAI (M.S.) INDIA

$\overline{\text { D.J. PATEL }, \bar{B} . \bar{A} \text {. Collage of Agriculture, Anand Agricultural University, ANAND }}$ (GUJARAT) INDIA

$\overline{\text { S.J. }} \overline{\text { PATIL, }} \overline{\text { Regional }} \overline{\text { Horticultural Research Station (N.A.U.), NAVSARI (GUJARAT) }} \overline{-} \overline{-}$ INDIA 